\title{
THE ELECTROCHEMICAL KINETIC BEHAVIOUR OF NICKEL IN ACID AQUEOUS SOLUTIONS CONTAINING CHLORIDE AND PERCHLORATE IONS*
}

\author{
R. C. V. Piatti, A. J. Arvia and J. J. Podestá \\ Instituto Superior de Investigaciones, Facultad de Ciencias Exactas, and \\ Departamento de Ingenieria Química, Facultad de Ingenieria, Universidad \\ Nacional de La Plata, La Plata, Argentina
}

\begin{abstract}
The electrochemical behaviour of polycrystalline nickel in acid solutions containing large excess either of $\mathrm{NaCl}$ or $\mathrm{NaClO}$, has been investigated, at potentials either more positive or negative than the rest potential of the metal. The electrode reactions were studied over a wide range of experimental conditions ( $\mathrm{pH}$, nickelous ion activity, temperature), and the influence of each variable on the experimental kinetic parameters has been determined.
\end{abstract}

Résumé-On a étudié le comportement electrochimique du nickel polycristallin dans des solutions acides $2 \mathrm{M}$ de $\mathrm{NaCl}$ ou $\mathrm{NaClO}_{4}$, à des potentiels plus positifs ou plus négatifs que le potentiel résiduel du métal. Les réactions d'électrode furent étudiés dans des conditions expérimentales trés varibes (pH, activité de l'ion nickel, température), et on a déterminé aussi l'influence de chaque variable sur les paramètres cinétiques expérimentaux.

Zusammenfassung - Es wurde das elektrochemische Verhalten von polykristalinem Nickel in sauren

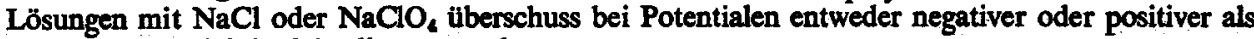
das Ruhepotential des Metalls untersucht.

Der Einfluss der experimentellen Bedingungen (wie pH, Nickelion Aktivităt, Temperatur) auf die kinetischen Parameter wurde bestimmt.

\section{INTRODUCTION}

THE ELECTROCHEMICAL behaviour of nickel in aqueous electrolyte solutions has been considered under three different headings, namely, the cathodic deposition, the anodic dissolution and the passive state of the metal. Literature about these problems is quoted in date order. ${ }^{1-51}$ Many investigations on the electrodeposition of nickel have been made ${ }^{11-14}$ from the viewpoint of the structure of nickel electrodeposits and the influence of the codeposition of hydrogen. Much attention has been paid to the latter point as it affects the structure of nickel due to the interaction of hydrogen atoms with the metal surface and further diffusion and solubility of hydrogen gas in the bulk of the metal. ${ }^{15-40}$

The study of the anodic dissolution of the metal has been made in close relation with the electropolishing ${ }^{38.39}$ and the passivation of the metal. ${ }^{40-51}$ In both these processes the participation either of a nickel oxide film of monolayer thickness, or of oxygen chemisorption, has been discussed. ${ }^{32,53}$ The latter process is also related to oxygen penetration into the metal ${ }^{54.55}$ and the change of work function resulting from the interaction of oxygen with clean nickel surfaces. ${ }^{56-58}$

The electrochemical behaviour of nickel depends on the kind of ions, particularly anions, present in the solution. ${ }^{59-63}$ In recent papers dealing with the kinetics of the anodic dissolution of nickel in sulphuric acid solutions ${ }^{32}$ and the kinetics of the anodic dissolution and cathodic deposition of nickel in acid perchlorate solutions, ${ }^{42}$ results are interpreted with different mechanisms, although the hydroxyl ion participates in

- Manuscript received 1 April 1968. 
both reaction schemes. In spite of this large amount of work on the electrochemistry of nickel, the mechanisms of the different processes involved in nickel electrodeposition, dissolution or passivation, are not yet definitely established. In this sense metals of the same type of electronic configuration, such as cobalt and particularly iron, seem to be rather better known. ${ }^{64-73}$ The reaction mechanisms proposed for these metals have been extended to nickel electrodes. It is very difficult to draw a definite conclusion concerning the reaction mechanism of the anodic dissolution of metal unless all kinetic parameters and their dependence on $\mathrm{pH}$ and ionic concentration are established unambiguously.

As there is yet no commonly accepted mechanism of the anodic dissolution of nickel, the present investigation is mainly concerned with the anodic region prior to the establishment of a definite passivity and to the cathodic region related both to hydrogen evolution and nickel electrodeposition, these reactions being studied under a wide range of experimental conditions and in the presence either of chloride or perchlorate anions. Taking into account the electronic configuration of solid nickel, it is of interest to compare the electrochemical behaviour of the metal with that of iron under the same environmental conditions.

\section{EXPERIMENTAL TECHNIQUE}

The electrolysis cell was essentially the same as that described previously. ${ }^{\text {71 }}$ Nickel wires of $1.0 \mathrm{~mm}$ diameter (Jolnnston, Matthey and Co.) were used. The analysis of the metal samples yields 99.8 percent $\mathrm{Ni}$ and traces of $\mathrm{Fe}, \mathrm{Mn}, \mathrm{Si}$ and $\mathrm{Mg}$. Nickel electrodes were polished to a mirror surface with finest alumina, cleaned and rinsed with distilled water and dipped into the acid nickelous solution for a short time before use in the run, so that reproducible surfaces were obtained.

Saturated calomel electrodes were used for reference. Calibrated glass electrodes (Radiometer G-202 B) were used for $\mathrm{pH}$ measurements. The technique followed for the preparation of the electrodes and assembling the cell was the same as described elsewhere. ${ }^{71.72}$

Solutions of nickel perchlorate and nickel chloride were prepared from Merck p.a. chemicals, previously purified, and triply distilled water. Solutions in the range from about 0 to $6.5 \mathrm{pH}$ were used, the $\mathrm{pH}$ being adjusted with perchloric acid (Mallinckrodt, p.a.), or hydrochloric acid (B.D.H. AnalaR) in order to have only one kind of anion in the solutions. Sodium perchlorate or sodium chloride were used, respectively, to maintain an excess of electrolyte in the solutions, approaching a constant ionic strength condition. Solutions were continuously stirred with hydrogen gas which was previously saturated at the same vapour pressure as the electrolytic solutions.

Anodic and cathodic runs were made at temperatures of 25,40 and $60^{\circ} \mathrm{C}$ with solutions of nickelous ion concentration ranging from 0.004 to $0.5 \mathrm{M}$, and a $2 \mathrm{M}$ concentration of sodium chloride or sodium perchlorate. Solutions of $\mathrm{pH}$ between 0.5 and 6.5 without nickel ion were used to obtain information about the cathodic evolution of hydrogen on nickel. These runs were performed at 25 and $40^{\circ} \mathrm{C}$.

\section{Anodic yield for nickel dissolution}

RESULTS

The anodic yield for nickel dissolution was determined by coulometry at different $\mathrm{pH}$ values in $2 \mathrm{M}$ sodium perchlorate and sodium chloride solutions. These experiments were done at different currents, $I$. The latter correspond to a region of current/ 
voltage curves where nickel dissolution occurs. The amount of dissolved nickel was determined by chemical analysis and checked by the weight loss of the nickel anode. Results are shown in Table 1. It is concluded that the anodic yield for nickel dissolution is practically $100 \%$ in the region of low anodic overvoltages.

TABle 1. ANODIC MieldS fOR Ni DISSOLUTION

\begin{tabular}{lcccc}
\hline \multicolumn{1}{c}{ Solution } & \multicolumn{2}{c}{$2 \mathrm{M} \mathrm{NaCl}$} & \multicolumn{2}{c}{$2 \mathrm{M} \mathrm{NaClO}_{4}$} \\
\hline pH & $0 \cdot 7$ & $4 \cdot 0$ & $0 \cdot 7$ & $4 \cdot 1$ \\
$I$ (average), $\mu \mathrm{A}$ & 115 & 100 & 110 & 90 \\
$t, s$ Weight of $\mathrm{Ni}, \mathrm{mg}\left(\begin{array}{l}\text { (a) } \\
\text { (b) }\end{array}\right.$ & 56,700 & 83,600 & 86,400 & 63,400 \\
& $2 \cdot 1$ & - & $3 \cdot 0$ & $1 \cdot 5$ \\
(c) & $2 \cdot 0$ & $2 \cdot 5$ & $3 \cdot 0$ & $1 \cdot 4$ \\
\hline
\end{tabular}

a; Chemical analysis (dimethyl-glyoxime).

b; Weight loss of nickel anode.

c; Theoretical yield.

\section{Current/voltage curves}

Anodic and cathodic steady current/voltage curves are plotted as electrode potential against $\log$ (total current density), the former being referred to the normal hydrogen scale, and the latter related to the apparent electrode area. Figures 1-4 are Tafel plots of current/voltage curves for chloride solutions and Figs. 5-7 refer to perchlorate solutions, at different concentrations and temperatures. They show that the initial potential, (rest potential), $E_{\mathrm{c}}$, is different from the potential which corresponds to the hydrogen electrode, $E_{\mathrm{H}}$, and the nickel/nickelous ion electrode, $E_{\mathrm{Nl}}$, and depends on pH. The nickelous ion activity was evaluated using activity coefficients taken from the literature.

The semilogarithmic plot of current-density/voltage curves shows a linear anodic region up to a current density of about $10^{-4} \mathrm{~A} / \mathrm{cm}^{2}$. If current is increased further, a rapid increase of overvoltage is observed leading to passivity of the nickel. The following kinetic parameters are obtained from the anodic curves: the anodic Tafel slope, $b_{\mathrm{a}, \mathrm{Ni}}$; an extrapolated current density, $\left(i_{0, \mathrm{Ni}}\right)_{\mathrm{a}}$, at $E_{\mathrm{Ni}}$ and an extrapolated current density, $i_{0, \mathrm{c}}$, at $E_{\mathrm{c}}$. The average value of $b_{\mathrm{a}, \mathrm{Ni}}$ at $25^{\circ} \mathrm{C}$ is close to $0.060 \mathrm{~V}$. $i_{0, \mathrm{~N} 1}$ and $i_{0,0}$ are $\mathrm{pH}$-dependent and their values are between $10^{-8}$ and $10^{-10} \mathrm{~A} / \mathrm{cm}^{2}$ for the former and between $10^{-5}$ and $10^{-6} \mathrm{~A} / \mathrm{cm}^{2}$ for the latter.

The initial portion of cathodic Tafel plots at low $\mathrm{pH}$ are mainly related to the hydrogen-evolution reaction, whereas at the higher current densities and high $\mathrm{pH}$, simultaneous deposition of hydrogen and nickel occurs. From the initial portion, at low $\mathrm{pH}$, the kinetic parameters of the hydrogen evolution reaction are obtained, namely, the Tafel slope, $b_{\mathrm{T}, \mathrm{H}}$ and two apparent current densities, $i_{0, \mathrm{H}}$ and $i_{0, \mathrm{c}}$ obtained respectively by extrapolation at $E_{\mathrm{H}}$ and $E_{\mathrm{c}}$. At lower $\mathrm{pH}$ the average value of $b_{\mathrm{T}, \mathrm{H}}$ is about $0.120 \mathrm{~V}$ at $25^{\circ} \mathrm{C}$. The values of $i_{0, \mathrm{H}}$ are of the order of $10^{-7} \mathrm{~A} / \mathrm{cm}^{2}$. At higher $\mathrm{pH}$ the limiting current density, $i_{\mathrm{L} . \mathrm{H}}$, is observed; this is related to the rate of diffusion of hydrogen ions, because of the depletion of these ions in the reaction interface. It increases linearly with the hydrogen-ion activity.

At a $\mathrm{pH}$ higher than 4, when potentials lower than $E_{\mathrm{N} i}$ are applied and nickel ions are present in the solutions, there is again a steady increase of log (current density) with potential, approaching a second cathodic Tafel region, corresponding to the simultaneous electrodeposition of nickel and hydrogen. The experimental 


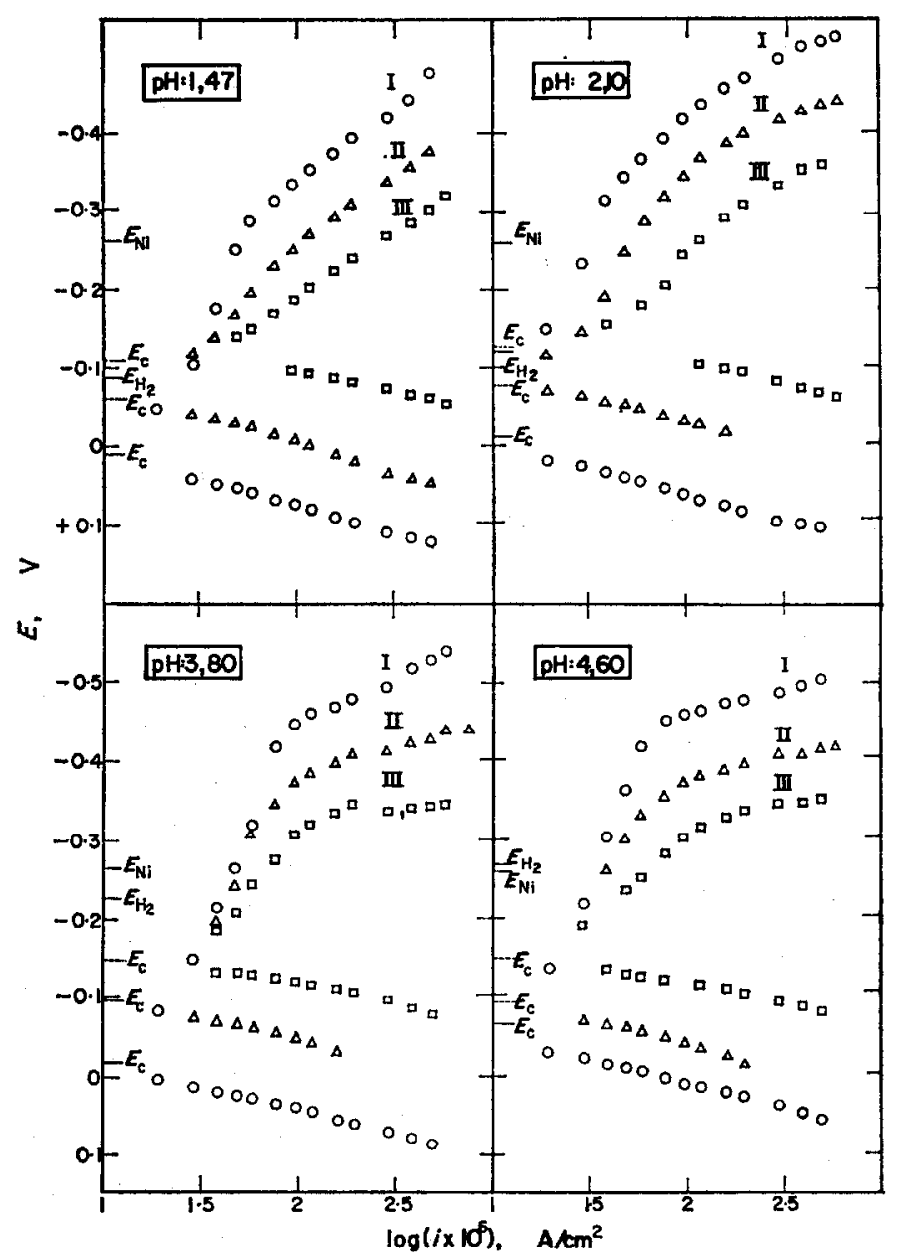

Fig. 1. Tafel plots. $C_{\mathrm{NHOl}_{2}}=0.5 \mathrm{M} ; C_{\mathrm{NaOI}}=2.0 \mathrm{M}$ I: $25^{\circ} \mathrm{C}$; II: $40^{\circ} \mathrm{C}$; III: $60^{\circ} \mathrm{C}$

Tafel slope, $b_{\mathbf{T}, 0}$, is about $0.060 \mathrm{~V}$ at $25^{\circ} \mathrm{C}$. To evaluate the cathodic Tafel line for the nickel deposition, the experimental line is corrected for the hydrogen evolution reaction, and plotted as $E$ vs $\log$ (current density) for nickel deposition. This is shown in Figs. 8 and 9. The Tafel line, in perchlorate solutions, yields a slope close to $2 R T / F$ in the range of $10^{-5}$ to $10^{-3} \mathrm{~A} / \mathrm{cm}^{2}$, at $\mathrm{pH}=4.5$ and $25^{\circ} \mathrm{C}$. The extrapolated exchange current density, $\left(i_{0, \mathrm{Ni}}\right)_{\mathrm{e}}$ at $E_{\mathrm{NI}}$, is $2 \times 10^{-6} \mathrm{~A} / \mathrm{cm}^{2}$. In chloride solutions, the cathodic Tafel line for nickel electrodeposition is not so well defined as for perchlorate solutions, although the curves exhibit the same features within a smaller current density region. The figure for $\left(i_{0, N i}\right)_{0}$ is not coincident with that resulting from the extrapolation of the anodic line at $E_{\mathrm{Ni}}$. The cathodic Tafel line for nickel electrodeposition could only be evaluated in the narrow $\mathrm{pH}$ range from 4 to 6 , approximately. In the absence of nickel ions, the cathodic Tafel slope related to the discharge of water is observed.

The various magnitudes were evaluated at different $\mathrm{pH}$, nickelous ion concentration and temperature, and the different relationships established between them are shown in Figs. 10-16. 


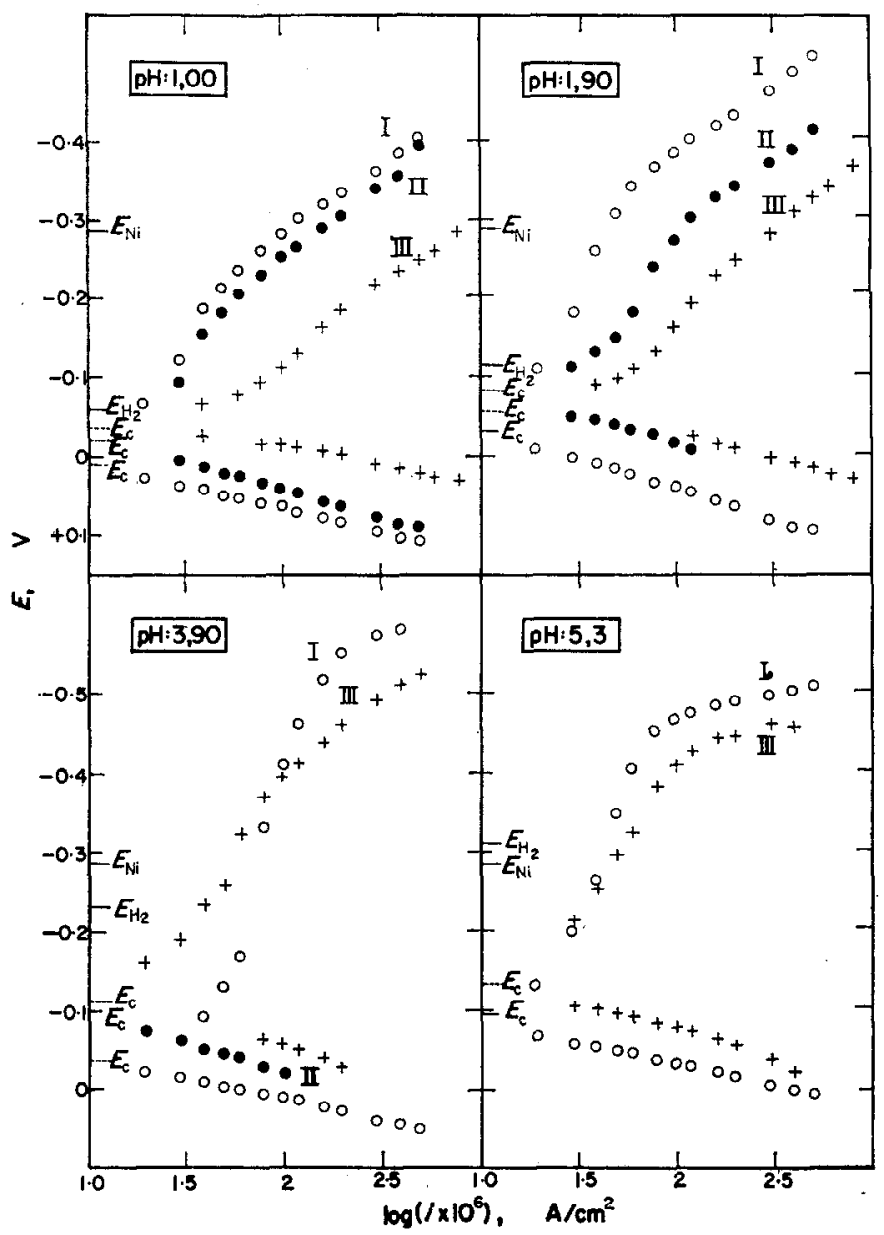

Fro. 2. Tafel plots. $C_{\mathrm{N} 101}=0.1 \mathrm{M} ; C_{\mathrm{NaO1}}=2.0 \mathrm{M}$

I: $25^{\circ} \mathrm{C}$; II: $40^{\circ} \mathrm{C}$; III: $60^{\circ} \mathrm{C}$

The discharge of hydrogen on nickel was studied in hydrochloric and perchloric acid solutions. The solution was stirred with hydrogen and the electrode was cathodically treated to an overvoltage at which hydrogen was freely evolved, so that the electrode rest potential was practically equal to the hydrogen electrode potential. At $25^{\circ} \mathrm{C}$ the cathodic Tafel slope for hydrogen on nickel was, between 0.120 and $0.130 \mathrm{~V}$, at low $\mathrm{pH}$. The kinetic parameters obtained for this reaction confirm previous studies, ${ }^{74}$ leading to the apparent conclusion that the reaction mechanism is governed by the discharge of a hydrogen ion on the metal surface as rate determining step.

\section{Temperature effect}

Increase of temperature causes the rest potential of nickel to move more active, as is observed in Figs. 1-7. An appreciable decrease of polarization both in the anodic and cathodic region is also observed when the temperature is increased. From data shown in Table 2, referring to anodic experiments, the average activation energy deduced for chloride solutions is $\Delta E_{\mathrm{a}}=13 \pm 3 \mathrm{kcal} / \mathrm{mole}$ and for perchlorate 


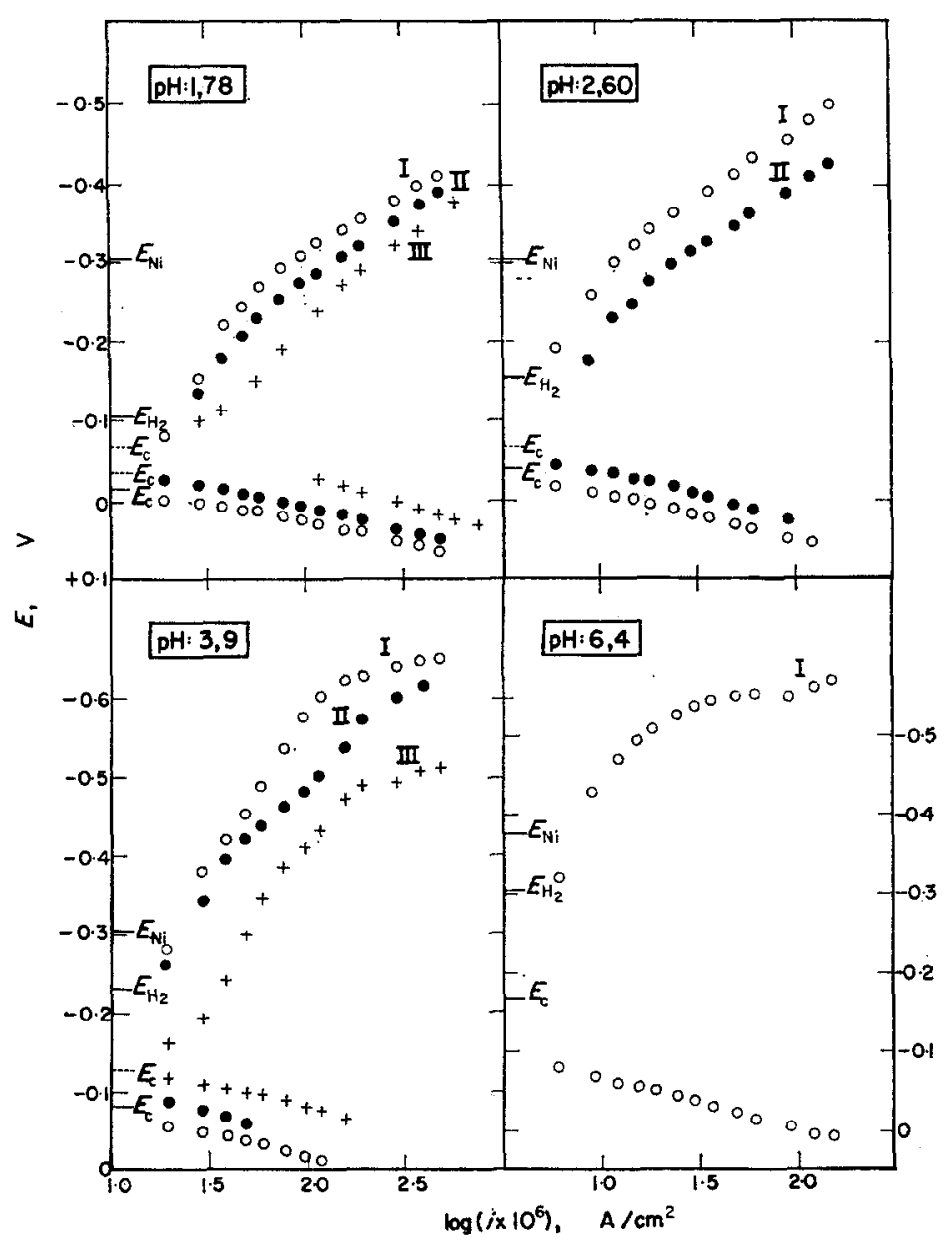

FIG. 3. Tafel plots. $C_{\mathrm{IICl}_{2}}=0.02 \mathrm{M} ; C_{\mathrm{XaO1}}=2.0 \mathrm{M}$ I: $25^{\circ} \mathrm{C}$; II: $40^{\circ} \mathrm{C}$; III: $60^{\circ} \mathrm{C}$.

solutions, $\Delta E_{\mathrm{a}}=18 \pm 3 \mathrm{kcal} / \mathrm{mole}$. An activation energy of the same order has also been found for nickel-copper and nickel-iron alloys. ${ }^{75}$

\section{INTERPRETATION AND DISCUSSION}

The rest potential of the nickel electrode

The initial potential of the nickel electrode, $E_{\mathrm{c}}$, in the acid solutions where oxygen was excluded, is independent of the nickelous ion activity, but depends on the hydrogen-ion activity as shown in Fig. 10. It was used as a reference to define the electrode overvoltage, independently of its actual physical meaning. Except at very low pH, it is difficult to assign the initial potential to a mixed potential related to a simple corrosion process involving nickel dissolution and hydrogen evolution because it appears more positive than the corresponding hydrogen and nickel electrode potentials. This means that as $\mathrm{pH}$ is increased, at least in the acid region, the nickel electrode shows increasing passivity. If there is a corrosion potential related to the oxidation of the metal and the simultaneous formation of hydrogen, it should correspond to a 


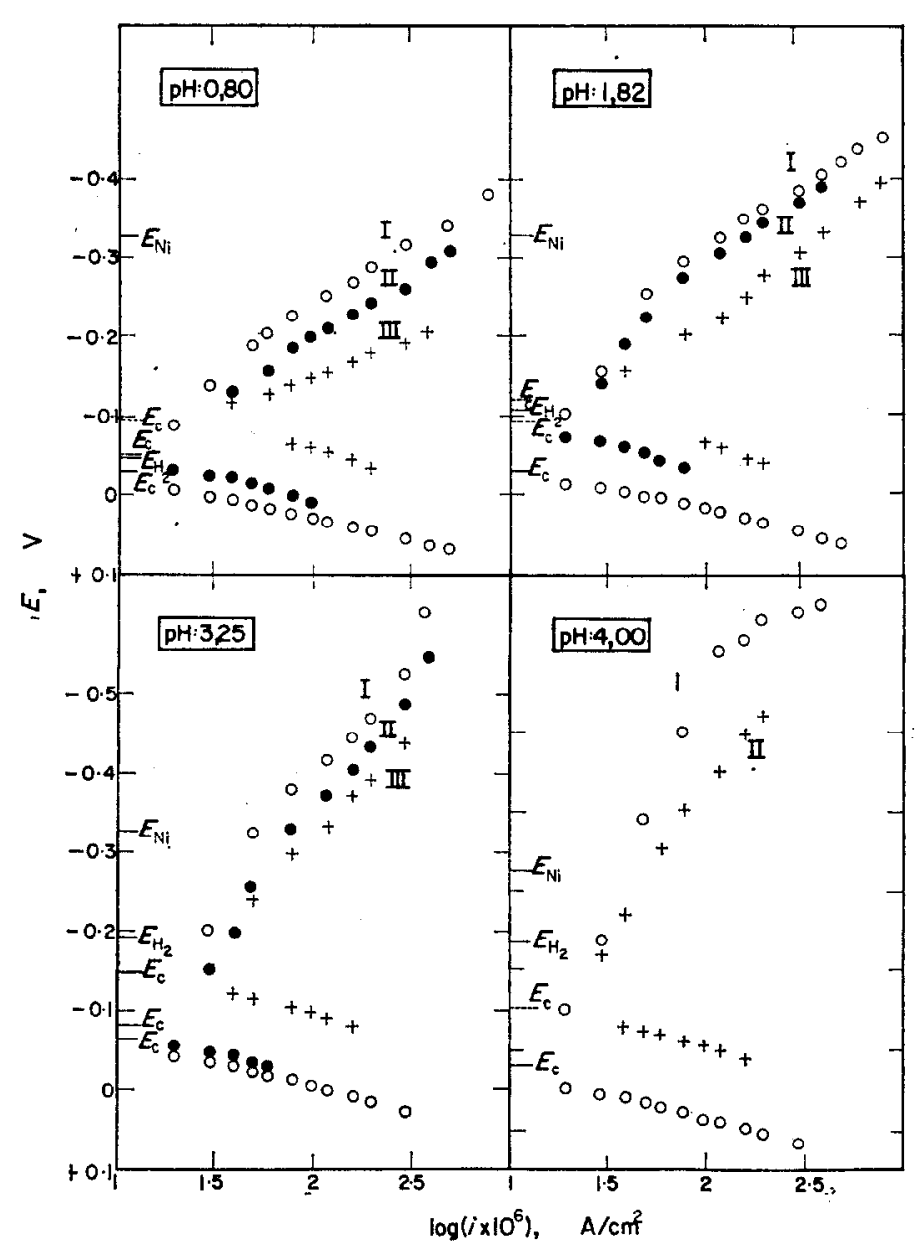

FIG. 4. Tafel plots. $C_{\mathrm{NIOl}_{2}}=0.004 \mathrm{M} ; C_{\mathrm{NaCl}}=2.0 \mathrm{M}$ I: $25^{\circ} \mathrm{C}$; II: $40^{\circ} \mathrm{C}$; III: $60^{\circ} \mathrm{C}$

single point in the potential/log (current density) diagram which is defined by the intersection of the Tafel lines of those processes.

After the definition of a corrosion potential, independently of the simultaneous processes occurring, it is possible to obtain a corrosion potential, $E_{\mathrm{c}_{1}}$ somewhat different from the initial potential, $E_{\mathrm{c}}$, at the intersection of the Tafel lines related to hydrogen evolution and to the anodic process. Values of $E_{\mathrm{c}_{1}} v s \mathrm{pH}$ are shown in Fig. 10. A corrosion current, $i_{0, c_{1}}$ is given at $E_{\mathrm{c}_{1}}$, which also depends on $\mathrm{pH}$ as shown in Fig. 11.

As deduced from steady overvoltage/log (current density) plots, the initial potential at higher temperatures and lower $\mathrm{pH}$ is more negative indicating that the nickel electrode becomes more active. While the metal exhibits a positive potential with respect to the hydrogen electrode at $25^{\circ} \mathrm{C}$, this becomes negative when the temperature is increased to 40 or $60^{\circ} \mathrm{C}$. In most of the experiments at lower $\mathrm{pH}$, the initial potential is close to the potential of the hydrogen electrode.

In the $\mathrm{pH}$ range from 1.55 to 12.5 the rest potentials of nickel electrodes have been 


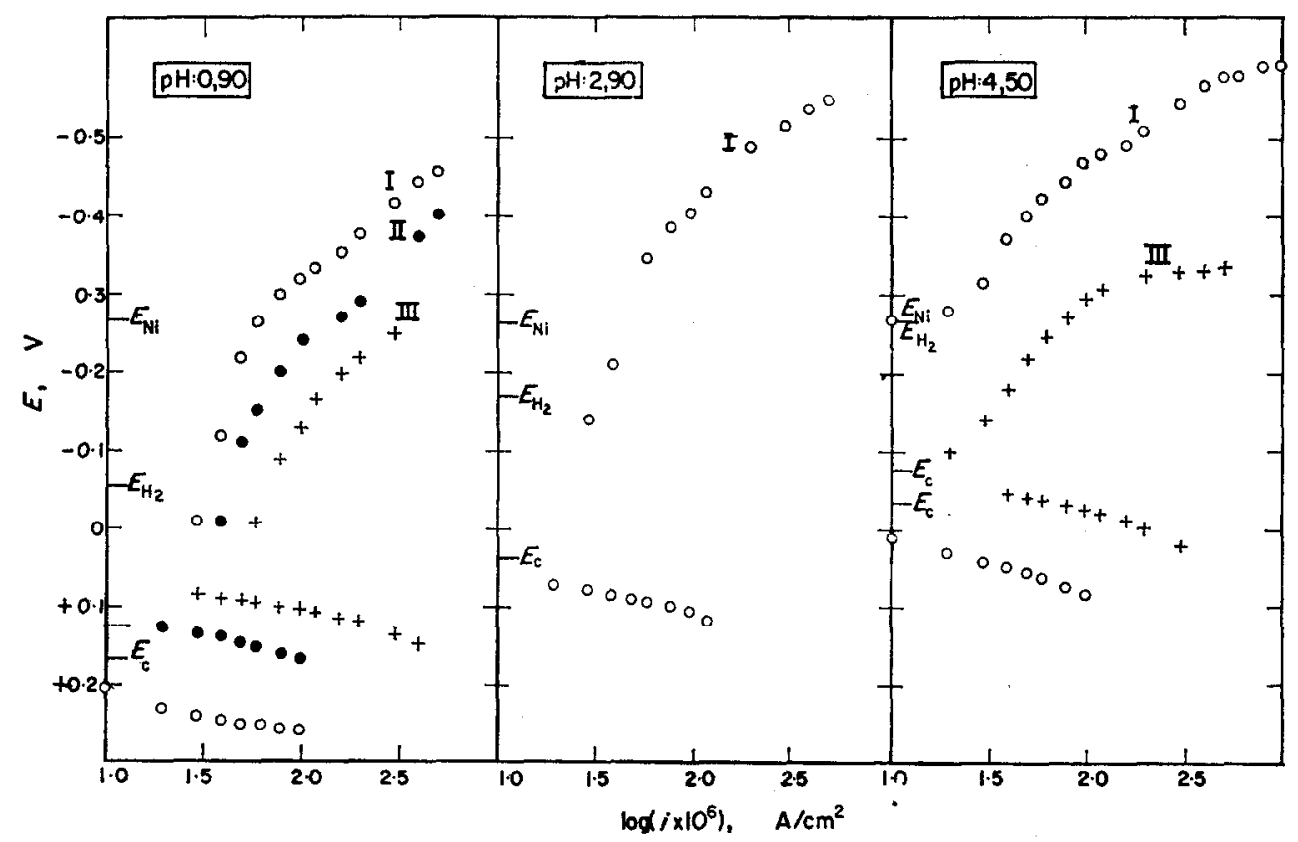

Fig. 5. Tafel plots. $C_{\mathrm{XIIClO}_{4}}=0.5 \mathrm{M} ; C_{\mathrm{NaO1O}_{4}}=2.0 \mathrm{M}$

I: $25^{\circ} \mathrm{C}$; II: $40^{\circ} \mathrm{C}$; III: $60^{\circ} \mathrm{C}$

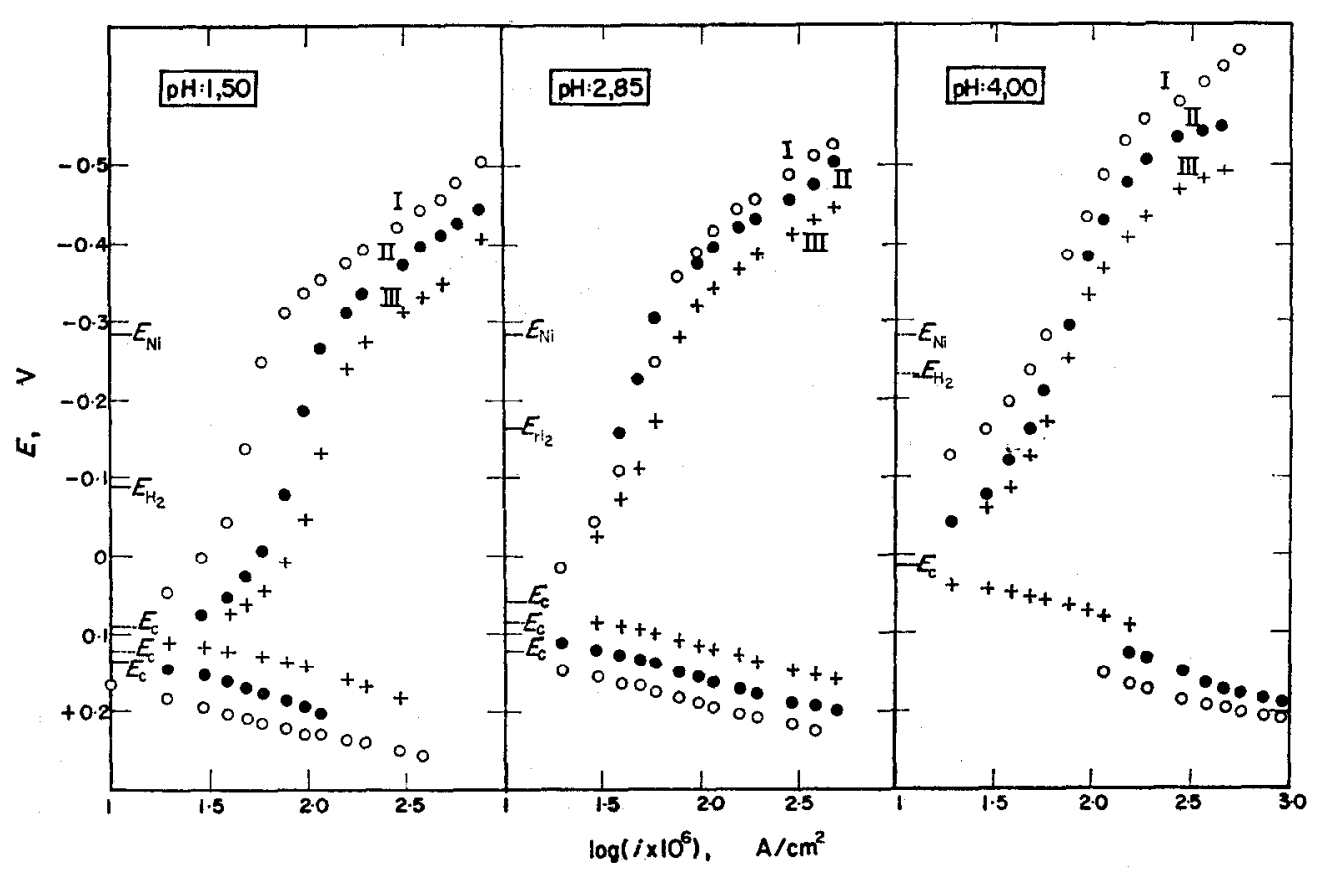

Fig. 6. Tafel plots. $C_{\mathrm{N}^{\prime\left(C 10_{4}\right) / 2}}=0.1 \mathrm{M} ; C_{\mathrm{NaClO}_{4}}=2.0 \mathrm{M}$

I: $25^{\circ} \mathrm{C}$; II: $40^{\circ} \mathrm{C}$; III: $60^{\circ} \mathrm{C}$ 


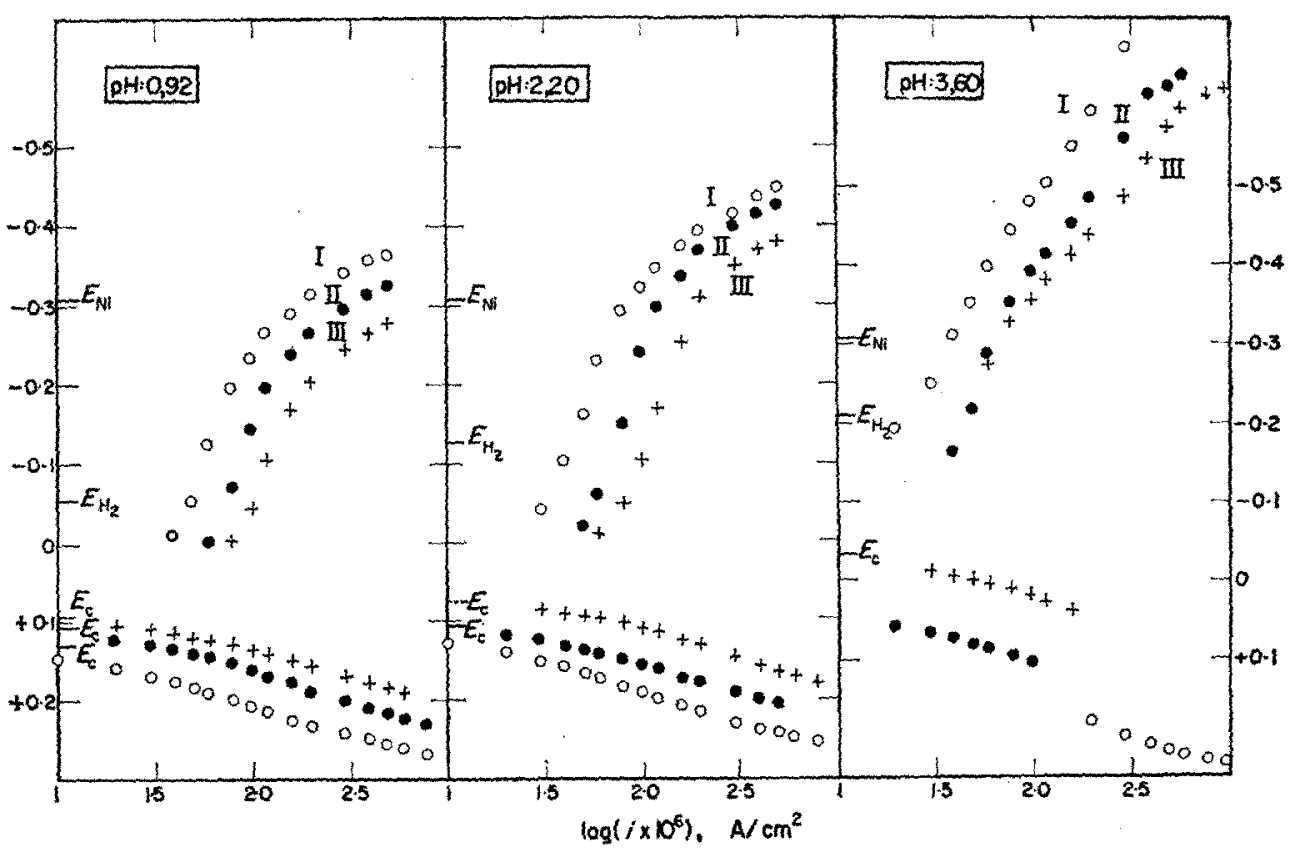

Fic. 7. Tafel plots. $C_{\left.\mathrm{X}_{11010}\right)_{3}}=0.02 \mathrm{M} ; C_{\mathrm{FaCrO}_{4}}=2.0 \mathrm{M}$ I: $25^{\circ} \mathrm{C}$; II: $40^{\circ} \mathrm{C}$; III: $60^{\circ} \mathrm{C}$

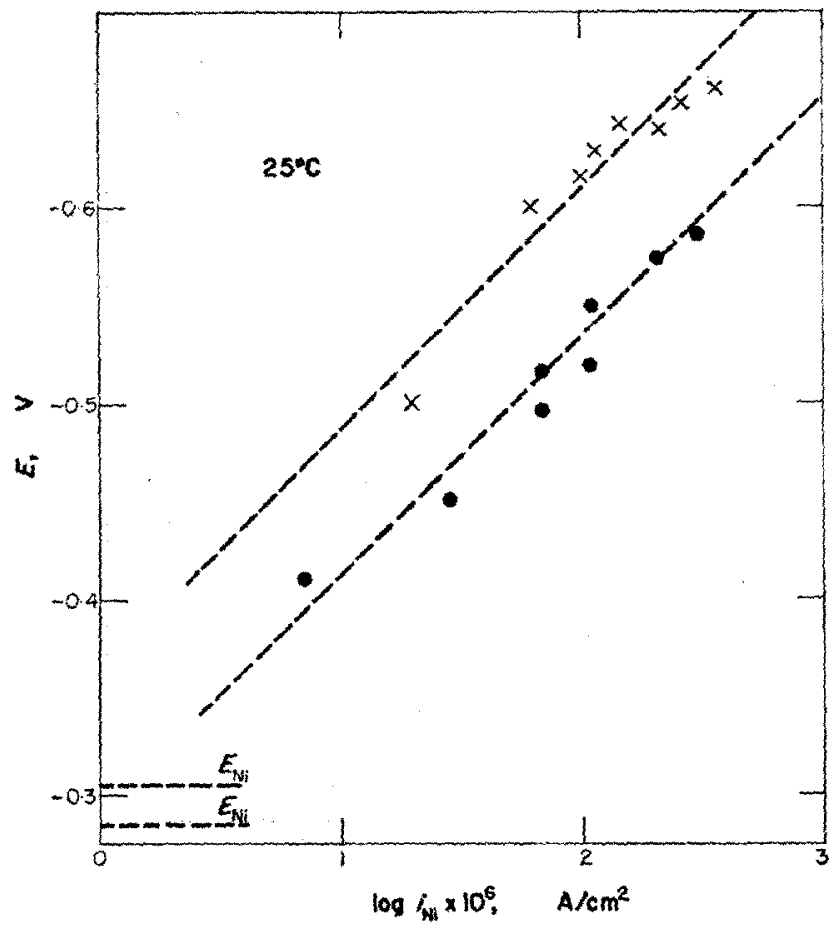

Frc. 8. Tafel plots for nickel deposition. $\times 0.02 \mathrm{M}$ $\mathrm{NiCl}_{2}, \mathrm{pH}^{2}=4.8 ; 0.1 \mathrm{M} \mathrm{NiCl}_{2}, \mathrm{pH}=3.9$. 


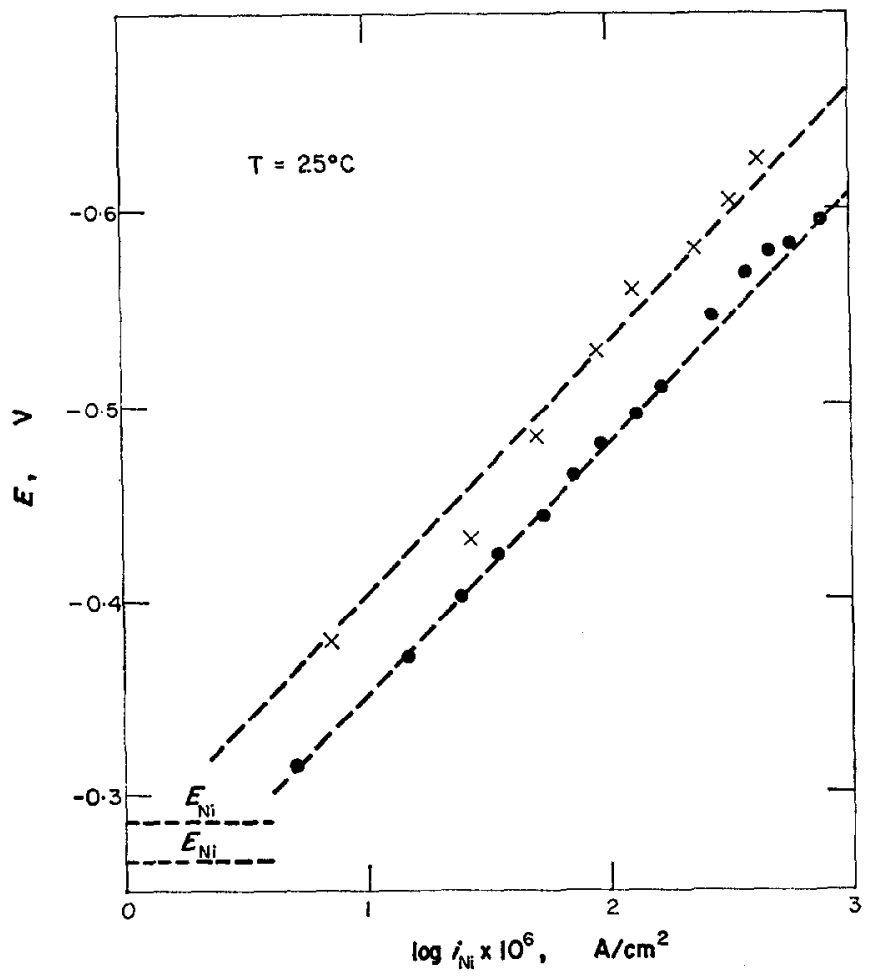

Fia. 9. Tafel plots for nickel deposition. $\times 0.1 \mathrm{M}$ $\mathrm{Ni}\left(\mathrm{ClO}_{4}\right)_{2}, \mathrm{pH}=4.0 ; 0.5 \mathrm{M} \mathrm{Ni}\left(\mathrm{ClO}_{4}\right)_{2}, \mathrm{pH}=4.5$.
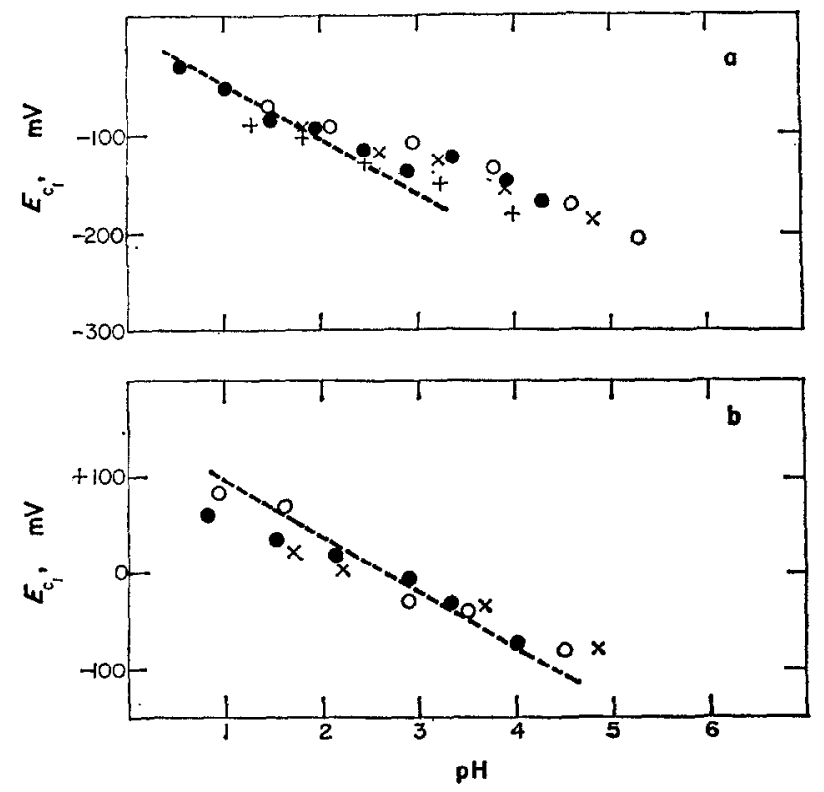

FIG. 10. Dependence of $E_{\mathrm{c}_{1}}$ on $\mathrm{pH} ; 25^{\circ} \mathrm{C}$.

(a) $2 \mathrm{M} \mathrm{NaCl}$ solutions.

(b) $2 \mathrm{M} \mathrm{NaClO}$, solutions.

$C_{\mathrm{N}_{1}^{2}+}: 0.5 \mathrm{M} ; \bullet 0.1 \mathrm{M} ; \times 0.02 \mathrm{M}$

Dotted lines corresponds to theoretical line from mechanism $\mathbf{A}$. 


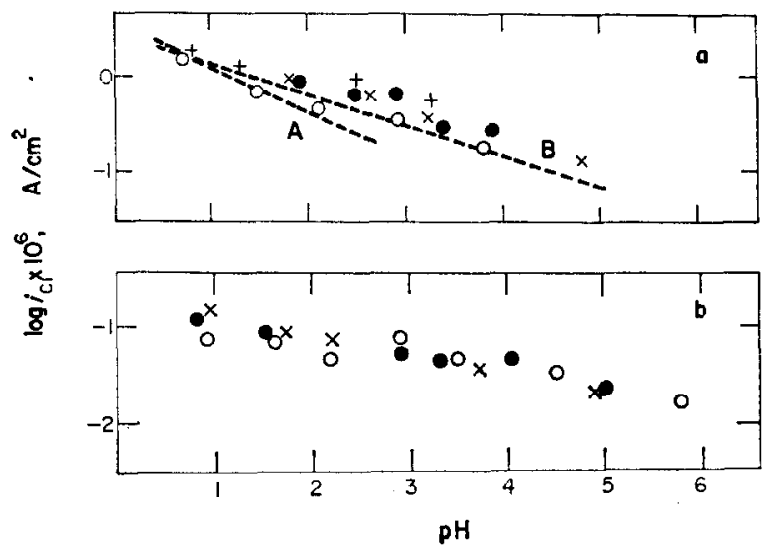

Fig. 11. Dependence of $\log i_{\mathrm{c}_{1}}$ on $\mathrm{pH} .25^{\circ} \mathrm{C}$.

(a) $2 \mathrm{M} \mathrm{NaCl}$ solutions.

(b) $2 \mathrm{M} \mathrm{NaClO}_{4}$ solutions.

$C_{\mathbb{N i}^{8+}}: \bigcirc 0.5 \mathrm{M} ; \bullet 0.1 \mathrm{M} ; \times 0.02 \mathrm{M} ;+0.004 \mathrm{M}$.
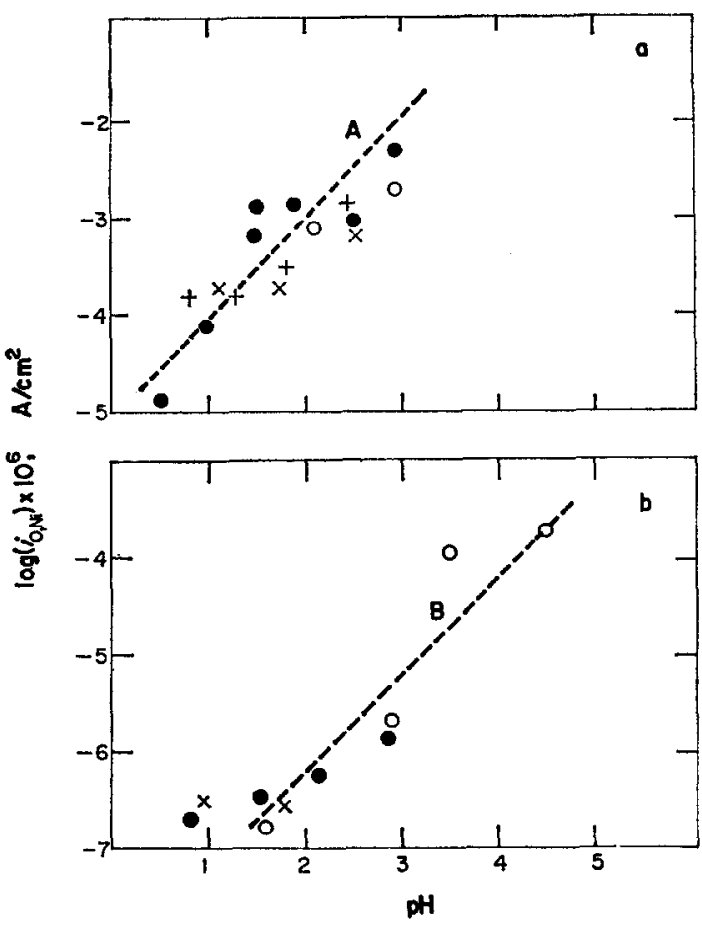

FIG. 12. Dependence of $\log \left(i_{0}, \mathrm{~N}_{1}\right)_{\mathrm{a}}$ on pH. $25^{\circ} \mathrm{C}$.

(a) $2 \mathrm{M} \mathrm{NaCl}$ solutions.

(b) $2 \mathrm{M} \mathrm{NaClO}$ solutions.

$C_{\mathrm{N}^{2+}}: 00.5 \mathrm{M} ; 0.1 \mathrm{M} ; \times 0.02 ;+0.004 \mathrm{M}$. 

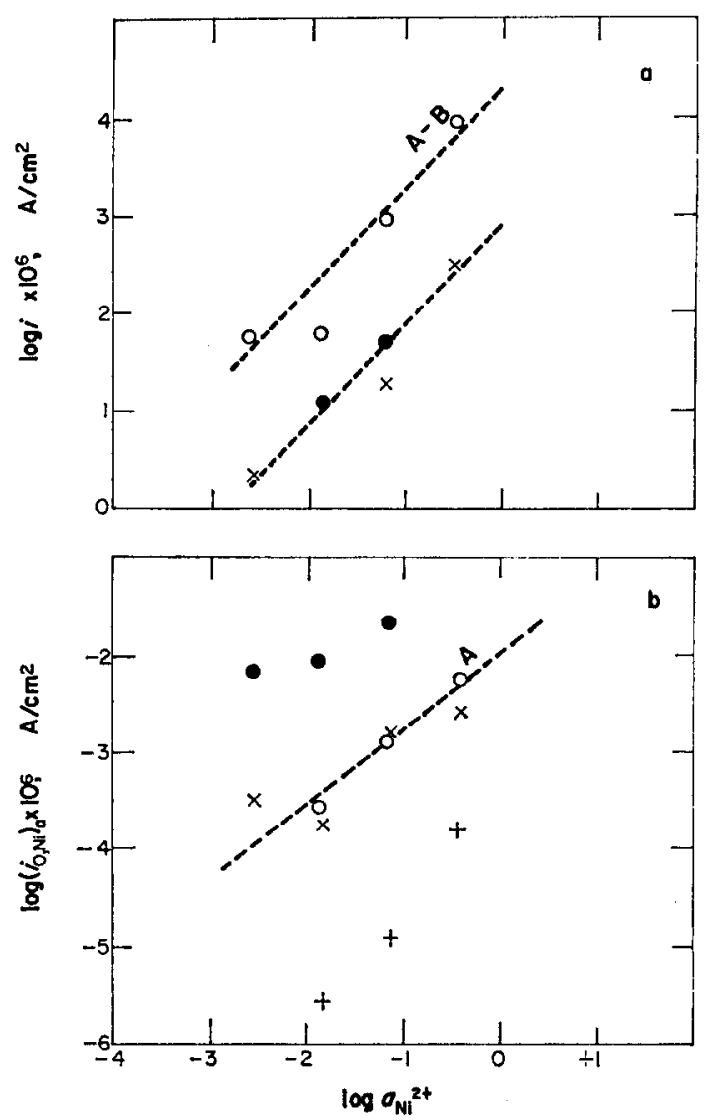

Fio. 13. (a) Dependence of cathodic current density on nickelous ion activity. $25^{\circ} \mathrm{C}$.

$O: 2 \mathrm{M} \mathrm{NaCl} ; \mathrm{pH}: 4 ; E=-0.6 \mathrm{~V}$.

×: $2 \mathrm{M} \mathrm{NaCl} ; \mathrm{pH}: 4 ; E=-0.5 \mathrm{~V}$.

: $2 \mathrm{M} \mathrm{NaClO}, \mathrm{pH}: 4 \cdot 5 ; E=-0.6 \mathrm{~V}$.

(b) Dependence of $\left(i_{0,111}\right)_{\mathrm{B}}$ on nickelous ion activity. $25^{\circ} \mathrm{C}$.

$$
\begin{aligned}
& \times: 2 \mathrm{M} \mathrm{NaCl} ; \mathrm{pH}=1.9 \\
& \mathrm{O}: 2 \mathrm{M} \mathrm{NaCl} ; \mathrm{pH}=4.0 \\
& : 2 \mathrm{M} \mathrm{NaCl} ; \mathrm{pH}=6.4 \\
& +: 2 \mathrm{M} \mathrm{NaClO} ; \mathrm{pH}=4.8
\end{aligned}
$$

studied by many authors, ${ }^{76-78}$ employing oxygen-free solutions containing phosphate ions, the potentials being compared with potentials of the nickel/nickel hydroxide and the hydrogen electrodes. At pH 1.55 the rest potential was higher than the former by $0.179 \mathrm{~V}$, while at $\mathrm{pH} 12.5$, it was lower by $0.155 \mathrm{~V}$. Other authors, ${ }^{79-81}$ have shown that the rest potential of nickel depends strongly on the structure of the metal surface. If a large amount of adsorbed hydrogen is present, the rest potential tends to behave as the potential of a hydrogen electrode.

Another fact to emphasize about the rest potentials is their clear dependence on the anion present in the system. Thus, at constant $\mathrm{pH}$ and temperature, the nickel electrode is more active (negative) in chloride solutions than in perchlorate solutions. This result is a consequence of the larger adsorbability expected for chloride as compared to perchlorate ions, as deduced from their respective polarizabilities. ${ }^{82}$ 


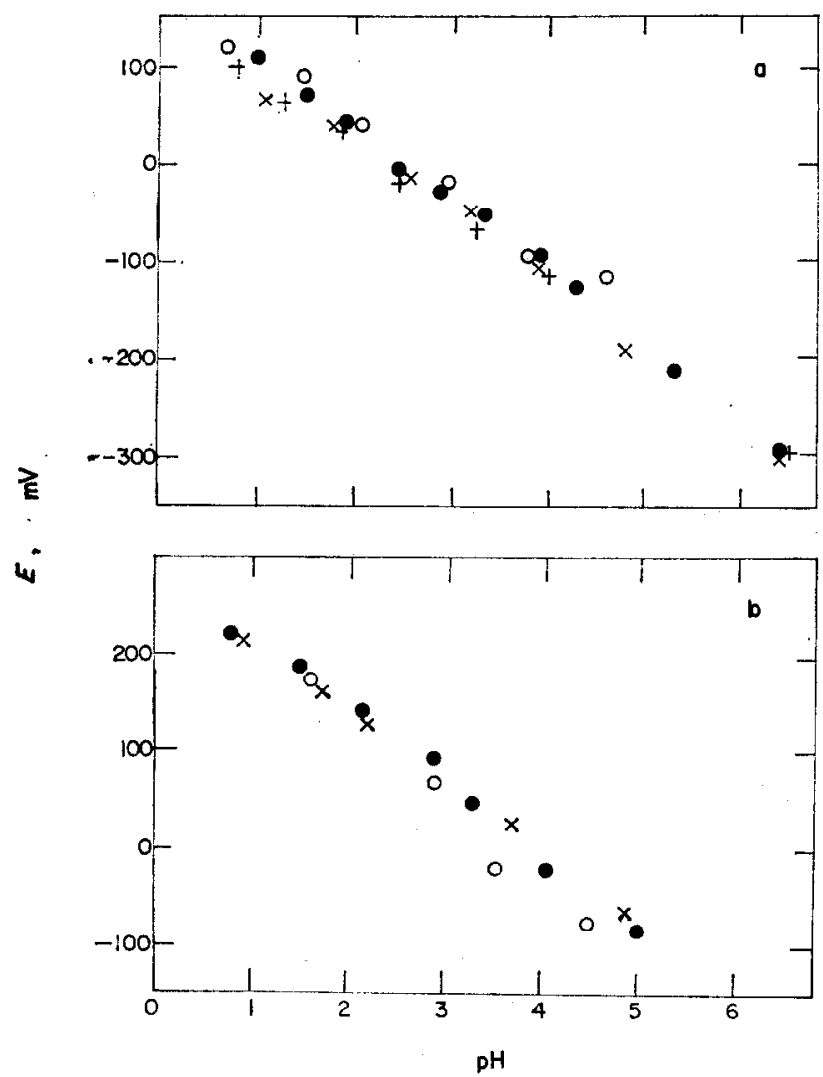

Frg. 14. Dependence of $E_{\mathrm{c}}$ on $\mathrm{pH}$.

(a) $2 \mathrm{M} \mathrm{NaCl}$ solutions.

(b) $2 \mathrm{M} \mathrm{NaClO}$, solutions.

$C_{\mathbb{N 1}}^{2+}: 00.5 \mathrm{M} ; 0.1 \mathrm{M} ; \times 0.02 \mathrm{M} ;+0.004 \mathrm{M}$.

This observation is in a good agreement with recent work ${ }^{\mathbf{6 1 . 6 2}}$ where it is shown that independently of the cause of nickel passivation, whether a chemisorbed film or solid oxide, the resistance of the latter on the metal can break down in the presence of halide ions $\left(\mathrm{Cl}^{-}, \mathrm{Br}^{-}\right.$, or $\left.\mathrm{I}^{-}\right)$and the metal become severely pitted. The above facts demand also the cautious use of the conventional potential/pH diagram for nickel.

For perchlorate solutions, where any adsorption effect would be relatively less important due to the symmetry of the ion, the nickel rest potential may be compared to those derived from the following equilibria:22,83

$$
\begin{aligned}
& \mathrm{Ni}+2 \mathrm{OH}_{\mathrm{aq}}{ }^{-}=\mathrm{NiO}+\mathrm{H}_{2} \mathrm{O}+2 \mathrm{e} . \\
& \mathrm{Ni}+2 \mathrm{OH}_{\mathrm{aq}}-\mathrm{Ni}(\mathrm{OH})_{2}+2 \mathrm{e} \\
& E=-0.14-0.059 \mathrm{pH}, 25^{\circ} \mathrm{C} . \\
& \mathrm{Ni}+2 \mathrm{H}_{2} \mathrm{O}=\mathrm{Ni}(\mathrm{OH})_{2}+2 \mathrm{H}^{+}+2 \mathrm{e} \\
& E=0.110-0.059 \mathrm{pH}, 25^{\circ} \mathrm{C} . \\
& \mathrm{Ni}+2 \mathrm{H}_{2} \mathrm{O}=\mathrm{NiO} . \mathrm{H}_{2} \mathrm{O}+2 \mathrm{H}^{+}+2 \mathrm{e} .
\end{aligned}
$$




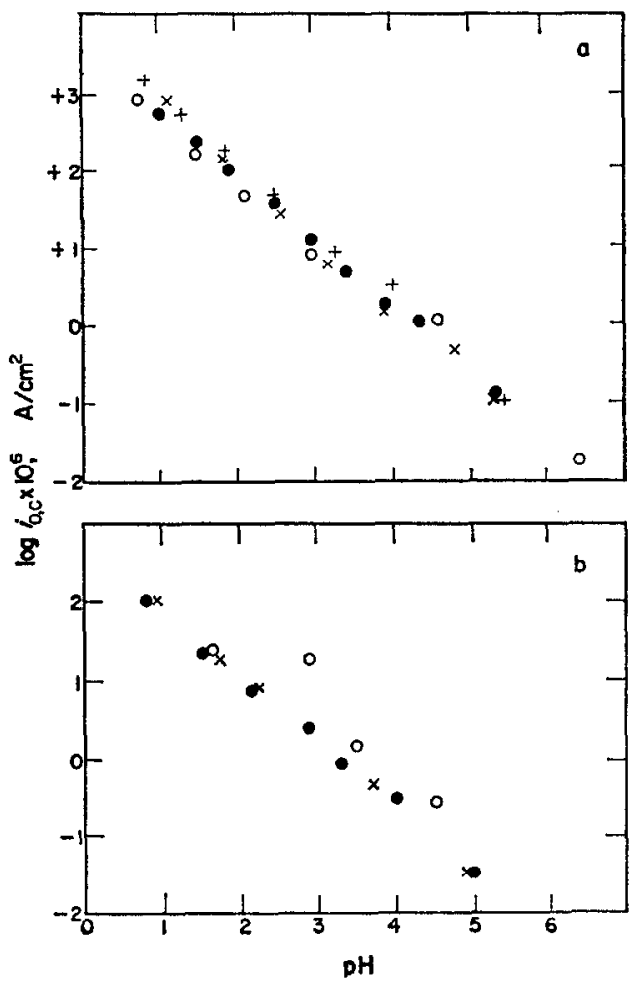

Fig. 15. Dependence of $i_{0, c}$ on $\mathrm{pH}$.

(a) $2 \mathrm{M} \mathrm{NaCl}$ solutions.

(b) $2 \mathrm{M} \mathrm{NaClO}$, solutions.

$C_{\mathrm{N} 1^{9+}}: 0.5 \mathrm{M} ; \bullet 0.1 \mathrm{M} ; \times 0.02 \mathrm{M} ;+0.004 \mathrm{M}$.

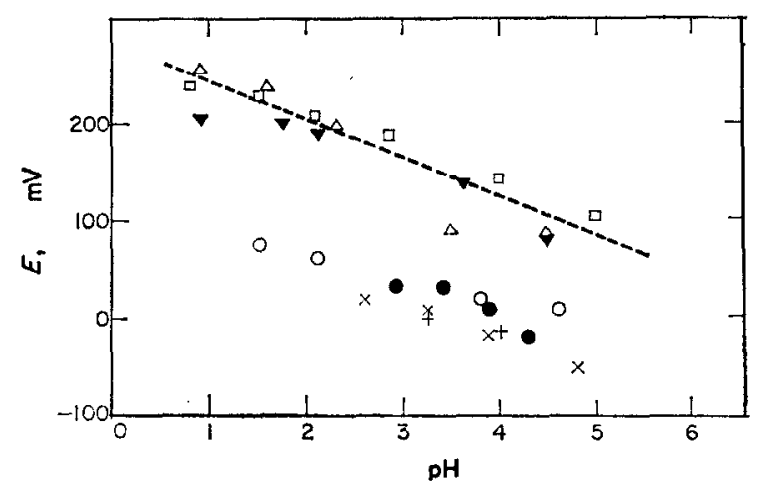

Fig. 16. Dependence of anodic potential (at $i=0.1 \mathrm{~mA} / \mathrm{cm}^{2}$ ) on $\mathrm{pH}$. $2 \mathrm{M} \mathrm{NaCl}$ solutions. $C_{\mathrm{N1}^{8+}}: 00.5 \mathrm{M} ; 0.1 \mathrm{M} ; \times 0.02 \mathrm{M} ;+0.004 \mathrm{M}$. $2 \mathrm{M} \mathrm{NaClO}_{4}$ solutions. $C_{\mathrm{N1}^{2+}}: \Delta 0.5 \mathrm{M} ; \square 0.1 \mathrm{M} ; \nabla 0.02 \mathrm{M}$. 
TABle 2. EFFECT OF TEMPERATURE ON ANOdIC CURRENT DENSITY

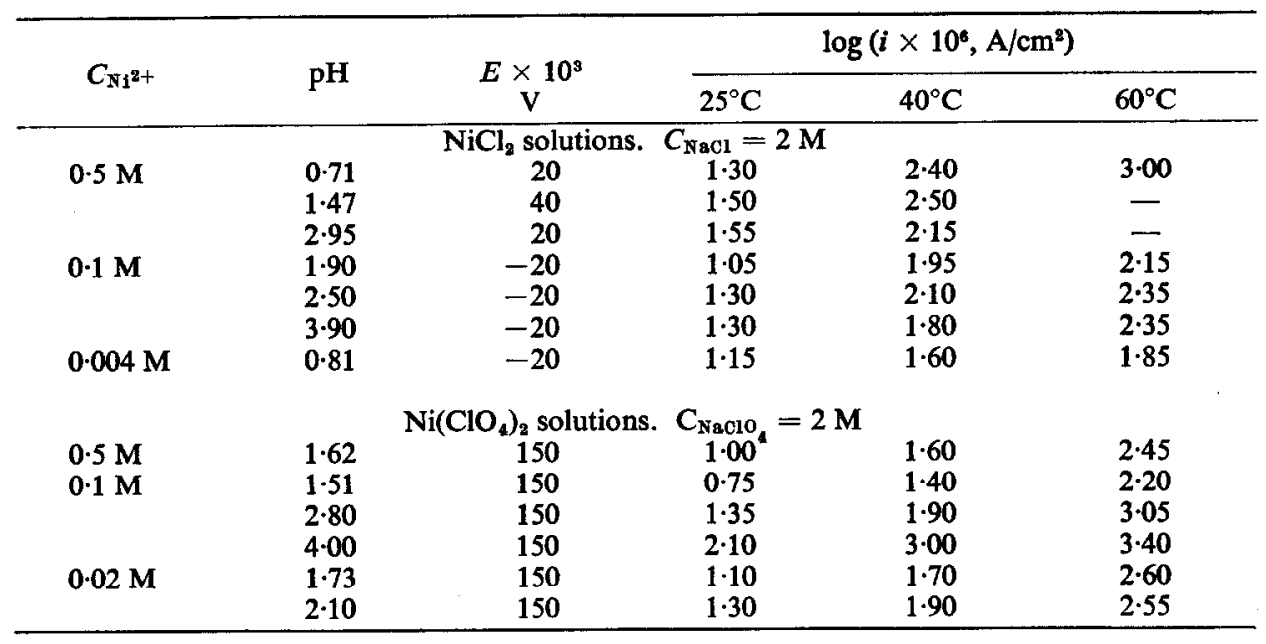

The standard electrode potential of reaction (IV) is very close to that of reaction (III) because the difference of the free energies of formation of $\mathrm{Ni}(\mathrm{OH})_{2}$ and $\mathrm{NiO} . \mathrm{H}_{2} \mathrm{O}$ is only $0.3 \mathrm{kcal} / \mathrm{mole}^{83}$

Those equilibria involving the interaction of the metal surface with either water molecules or hydroxyl ions, indicate that no clean nickel surface exists at equilibrium in aqueous solutions. Thus, from a different standpoint recent experiments on the adsorption of gases and vapours on pure metals at low temperature and pressure ${ }^{84-86}$ have shown that water vapour at $10^{-8} \mathrm{~mm} \mathrm{Hg}$ and $-78^{\circ} \mathrm{C}$, will decompose on a nickel surface, yielding hydrogen and leaving an oxidized surface.

Some time ago, reaction (IV) was ascribed to the passivation of nickel, ${ }^{\mathbf{4 6}}$ through the formation of a $\mathrm{NiO}$ film. It was stated that the Flade potential for nickel at $25^{\circ} \mathrm{C}$ is

$$
E_{\mathrm{F}}=0.355-0.059 \mathrm{pH},
$$

covering the $\mathrm{pH}$ range between 0 and 3. The constant is more positive than that of reaction (III) by $0.245 \mathrm{~V}$, in the passivated state.

The following conclusions are drawn from the rest potentials: (i) it is unlikely that in aqueous solutions a clean nickel/solution interface exists, (ii) the interface composition depends on the anion present in the solution and (iii) for perchlorate ions, their behaviour at low $\mathrm{pH}$ is represented by equation (III).

\section{A probable mechanistic interpretation of nickel behaviour in acid solutions}

The different kinetic parameters relevant from a mechanistic viewpoint are summarized in Table 3. The different reaction orders and Tafel slopes show that both the rate of nickel deposition and dissolution clearly depend on $\mathrm{pH}$. Consequently simple mechanisms such as

or

$$
\mathrm{Ni}^{2+}+2 \mathrm{e}=\mathrm{Ni}
$$

$$
\text { or }
$$

are discarded.

$$
\left\{\begin{array}{l}
\mathrm{Ni}^{2+}+\mathrm{e}=\mathrm{Ni}^{+} \\
\mathrm{Ni}^{+}+\mathrm{e}=\mathrm{Ni}
\end{array}\right.
$$


TABle 3. Theoretical KINETiC Parameters assuming $\beta=0.50$

\begin{tabular}{|c|c|c|c|}
\hline & Mechanism A & Mechanism B & Experimental $\left(25^{\circ} \mathrm{C}\right)$ \\
\hline$\left(\frac{\partial E}{\partial \ln i_{\mathrm{a}}}\right)_{a_{0 \mathrm{H}}-\mathrm{a}_{\mathrm{N} 1^{2+}}}$ & $\frac{2 R T}{3 F}$ & $\frac{R T}{F}$ & $0.055 \pm 0.005 \mathrm{~V}$ \\
\hline$\left(\frac{\partial E}{\partial \ln i_{\mathrm{c}}}\right)_{\mathrm{OOH}^{-}, a_{\mathrm{N1}^{2+}}}$ & $-\frac{2 R T}{F}$ & $-\frac{R T}{F}$ & $-0 \cdot 120 \pm 0.015 \mathrm{~V}$ \\
\hline$\left(\frac{\partial \ln i}{\partial \ln a_{\mathrm{N} 1^{3+}}}\right)_{a_{0 \mathrm{H}^{-}, \eta}}$ & 1 & 1 & $1.0 \pm 0.3$ \\
\hline$\left(\frac{\partial \ln i_{\mathrm{ON} 1}}{\partial \ln a_{0 \mathrm{H}^{-}}}\right)_{a_{\mathbb{N 1}^{2+}}}$ & 1 & 1 & $1 \cdot 0 \pm 0 \cdot 2$ \\
\hline$\left(\frac{\partial E}{\partial \ln a_{0 \mathrm{H}^{-}}}\right)_{\mathrm{a}_{\mathrm{N1}}{ }^{2+,}, \mathrm{f}}$ & $-\frac{2 R T}{3 F}$ & $-\frac{R T}{F}$ & $-0.040 \pm 0.005 \mathrm{~V}$ \\
\hline$\left(\frac{\partial \ln i_{0, \mathbb{N i}}}{\partial \ln a_{\mathbf{a}_{\mathbf{N 1}}{ }^{2+}}}\right)_{a_{\mathrm{OH}^{-}}}$ & 0.75 & 0.5 & $0.8 \pm 0.3$ \\
\hline$\left(\frac{\partial E_{\mathrm{c}}}{\partial \ln a_{0 \mathrm{H}^{-}}}\right)_{a_{\mathbb{N}^{3}} \mathbf{s}^{3+}}$ & $-\frac{R T}{F}$ & $-\frac{4 R T}{3 F}$ & $\begin{array}{l}-0.035 \pm 0.010\left(E_{\mathrm{c}_{1}} \text { vs } \mathrm{pH}\right) \\
-0.065 \pm 0.010\left(E_{\mathrm{c}} \text { vs } \mathrm{pH}\right)\end{array}$ \\
\hline$\left(\frac{\partial \ln i_{o, c}}{\partial \ln a_{0 H^{-}}}\right)_{a_{\mathbb{N}^{2}}+}$ & -0.5 & -0.33 & $-0.3 \pm 0.1\left(i_{0, c_{1}}\right.$ vs $\left.\mathrm{pH}\right)$ \\
\hline
\end{tabular}

There are two main drawbacks in advancing a reaction mechanism for nickel deposition and dissolution in aqueous acid solutions. First, the Tafel line for cathodic deposition of nickel does not intercept the anodic line at $E_{\mathrm{Ni}}$. Secondly, the initial potential is usually more positive than that expected for a simpler corrosion process where a metal is dissolved and hydrogen is evolved.

Other facts to consider in discussing the reaction mechanism are the $\mathrm{pH}$ change at the interface during the codeposition of hydrogen and nickel and the existence of the $\mathrm{NiOH}^{+}$ion which is already present at appreciable concentrations at low $\mathrm{pH}$. A straightforward comparison for the $\mathrm{pH}$ change between some experimental kinetic parameters and the theoretical one is not feasible. Therefore, the mechanism must comprise a series of consecutive steps, some of them related to adsorption processes at the interface.

Let the principal difficulties already mentioned be assigned to surface changes or changes in the oxide coverage of the metal and be neglected at present as well as any specific adsorption, and let us try to interpret the results in terms of a simple formal reaction scheme.

Independently of the initial state of the nickel surface, the anodic voltage/current density curve presents a region where the metal actually dissolves. Formally this is expressed as if a bare Ni surface reacts. When these assumptions are established, the dissolution and deposition of nickel, in so far as the kinetic parameters are concerned, is very close to the dissolution and deposition of active iron in acid media, and most of the kinetic analysis made for the latter ${ }^{64}$ can be extended to the former metal.

Let us compare these results with the theoretical kinetic analysis in terms of two possible reaction schemes already used for the kinetic analysis of the iron electrode. ${ }^{64}$ Let us call them Mechanism A and Mechanism B. 
Mechanism A

Anodic reaction: $\mathrm{Ni}+\mathrm{H}_{2} \mathrm{O} \rightleftarrows(\mathrm{NiOH})_{\mathrm{ads}}+\mathrm{H}^{+}+\mathrm{e}$

$(\mathrm{NiOH})_{\mathrm{ads}} \stackrel{\text { r.d.s. }}{\longrightarrow} \mathrm{NiOH}^{+}+\mathrm{e}$

$$
\mathrm{NiOH}^{+} \rightleftharpoons \mathrm{Ni}^{2+}+\mathrm{OH}^{-} \text {. }
$$

Cathodic reaction: $\mathrm{Ni}^{2+}+\mathrm{H}_{2} \mathrm{O} \rightleftarrows \mathrm{NiOH}^{+}+\mathrm{H}^{+}$

$$
\begin{aligned}
& \mathrm{NiOH}^{+}+\mathrm{e} \stackrel{\text { r.d.s. }}{\longrightarrow}(\mathrm{NiOH})_{\mathrm{ads}} \\
& \mathrm{Ni}(\mathrm{OH})_{\mathrm{ads}}+\mathrm{H}^{+}+\mathrm{e} \rightleftharpoons \mathrm{Ni}+\mathrm{H}_{2} \mathrm{O} .
\end{aligned}
$$

Mechanism B

Anodic reaction: $\mathrm{Ni}+\mathrm{OH}^{-} \stackrel{\text { r.d.s. }}{\longrightarrow}\left(\mathrm{NiOH}^{+}\right)_{\mathrm{ad}}+2 \mathrm{e}$

$$
\mathrm{NiOH}^{+} \rightleftarrows \mathrm{Ni}^{2+}+\mathrm{OH}^{-}
$$

Cathodic reaction: $\mathrm{Ni}^{2+}+\mathrm{H}_{2} \mathrm{O} \rightleftarrows\left(\mathrm{NiOH}^{+}\right)+\mathrm{H}^{+}$

$$
\mathrm{NiOH}^{+}+2 \mathrm{e} \stackrel{\text { r.d.s. }}{\longrightarrow} \mathrm{Ni}+\mathrm{OH}^{-} \text {. }
$$

Theoretical kinetic parameters deduced from Mechanisms $\mathrm{A}$ and $\mathrm{B}$ are assembled in Table 3, where it is assumed that the symmetry factor of the rate determining step is $\frac{1}{2}$. A straightforward comparison with those derived from the experimental results can be made. A better comparison between the predictions of the mechanisms and the values obtained from the experimental results, as well as an idea of the deviations, is given by plotting the corresponding data, as shown in Figs. 10-16.

From the above mentioned analysis, in principle Mechanism A explains formally most of the experimental results particularly at low pH. However, the anodic Tafel slope is larger than the predictions of Mechanism A but coincides with the theoretical anodic Tafel slope derived from Mechanism B. Notwithstanding, a slope larger than $\frac{2}{3}(R T / F)$ is not surprising if the electron transfer in the anodic reaction takes place not on a bare metal surface but on a surface covered by a film of the oxide type. Therefore, if this additional fact is taken into account, the general consideration of the kinetic parameters favours Mechanism A over Mechanism B. This being so, the kinetics and mechanism related to the dissolution of nickel in acid aqueous solutions are explained by the same reaction scheme already discussed for the iron electrode under the same circumstances.

\section{The effect of specific adsorption on the kinetics of the electrode process}

A clear effect of the anion was particularly observed on the rest potential, which became more active in the presence of chloride ions. This sort of effect has already been observed in the anodic dissolution of iron in acid aqueous media and was essentially attributed to the very structure of the ionic species, which is reflected in the ionic polarizability as already indicated. ${ }^{73}$

The effect of chloride ion manifests itself preferentially in two distinct manners:

(i) The specific adsorption decreases the potential of the inner plane of the Helmholtz double layer, $\phi_{2}{ }^{i}$, causing an increase of the rate of dissolution, as it is related to the overvoltage, $\eta$, by the equation ${ }^{82}$

$$
\eta=\frac{R T}{z \beta F} \ln \frac{i_{\mathrm{a}}}{i_{0}}+\phi_{2}{ }^{1}
$$


(ii) If chloride ions prevent any reaction of the metal with water or hydroxyl ions by covering the metal surface, the rate of the corrosion reaction is decreased, as occurs particularly with iron in concentrated aqueous chloride solutions. On the other hand, for nickel electrodes effect (i) predominates over (ii).

Assuming that the nickel surface is not completely free of oxygen containing species, it is likely that chloride-ion interaction takes place through this sort of layer. It probably occurs by overlapping of the chloride-ion orbitals, which are distorted due to the high local field strength at the electrical double layer, with part of the orbitals of nickel. The participation of these orbitals requires a kind of distorted ligand.

The outer electronic structure of solid nickel as previously indicated ${ }^{21,33}$ results from a statistical average of at least three states $(3 d)^{10}(4 s)^{0},(3 d)^{9}(4 s)^{1}$ and $(3 d)^{8}(4 s)^{2}$. The average value may be written as $(3 \mathrm{~d})^{9.4}(4 \mathrm{~s})^{0.6}$ indicating that the $\mathrm{d}$-orbital contribution in the solid is more relevant than in the free gaseous nickel atom in the normal state. Taking into account that aqueous nickel ion has a $(3 \mathrm{~d})^{8}(4 \mathrm{~s})^{2}$ configuration, it is evident that an electronic energy redistribution must occur for the dissolution as well as the electrodeposition process to occur. As far as the electronic structure and the participation of chloride ions is concerned, the effect of the latter, through its adsorption on the metal, may promote d-electrons, making the dissolution process easier. In fact, the overlapping of orbitals in this type of interface and surface complex formation, particularly of chloride ions, on different transition metals has already been emphasized. ${ }^{63.87}$ The interaction of chloride ions reflects in the kinetics of the processes. Although the Tafel slope is unaltered, the magnitude of the pre-exponential factor in the rate equation and the temperature dependence of the extrapolated current densities are changed. A mechanistic picture of the electrode process, including the effect of anion adsorption, will be reported later.

Acknowledgement-This work was supported in part by funds provided by the Consejo Nacional de Investigaciones Cientificas y Técnicas of Argentina.

\section{REFERENCES}

1. S. GLasstone, J. chem. Soc. 2887 (1926).

2. F. FÖRSTER and F. KRÜGER, Z. Elektrochem. 33, 418 (1927).

3. J. B. O'Sullivan, Trans. Faraday Soc. 26, 533 (1930).

4. N. IsGarischev and H. RavikovitsCh, $Z$. phys. Chem. 140, 235 (1929).

5. T. ERDEY-GruZ and M. Volmer, $Z$. phys. Chem. 157, 165 (1931).

6. F. Förster and K. Grorgi, Z. phys. Chem., Bodenstein Festband, 453 (1931).

7. O. Essin and M. LoschKaREv, Zh. fiz. Khim. 13, 186 (1939).

8. V. JUZA and L. KoPYL, Zh. fiz. Khim. 14, 1074 (1940).

9. R. VerDiECK, M. J. KSYCKI and L. F. YNTEMA, Trans. electrochem. Soc. 80, 41 (1941).

10. S. P. Makarieva, Bull. Acad. Sci. URSS, 573 (1941); C.A. 37, 2272 (1943).

11. F. W. SALT, Discuss. Faraday Soc. 1, 169 (1947).

12. G. I. FINCH, H. WILMAN and L. YANG, Disc. Faraday Soc. 1, 144 (1947).

13. G. E. GARDAM, Discuss. Faraday Soc. 1, 182 (1947).

14. A. HICkLING and J. E. SPICE, Trans. Faraday Soc. 43, 762 (1947).

15. A. T. VAGRAmYAN and Z. A. Solov'Eva, Dokl. Akad. Nauk. USSR 77, 629 (1951).

16. D. R. TURNER, J. electrochem. Soc. 98, 434 (1951).

17. S. V. GorbacheV and YU. N. YURKeviCH, Zh. fiz. Khim. 28, 1120 (1954). C.A. 49, $751 \mathrm{~g}$ (1955).

18. H. REISER and H. Fischer. Z. Elektrochem. 58, 668 (1954).

19. H. Fischer, M. SEIPT and G. MORLOCK, Z. Elektrochem. 59, 440 (1955).

20. H. REISER and H. Fischer. Z. Elektrochem. 59, 768 (1955).

21. W. A. WESLEY, J. electrochem. Soc, 103, 296 (1956).

22. R. Piontelli and G. SerRavalle, $Z$. Elektrochem. 62, 759 (1958).

23. J. K. HigGINs, J. electrochem. Soc. 106, 999 (1959).

24. J. Yeager, J. P. Cels, E. Yeager and F. HovorKa, J. electrochem. Soc. 106, 308 (1959). 
25. V. I. Kravtsov and ChzHI-Bin ChzhaN, Vestnik. Lening. Univ. 14, 81 (1959).

26. Cimh-Ping Chang, V. I. Kravtsov and YA. V. Durdin, Zh. fiz. Khim. 34, 2041 (1960).

27. V. I. Kravtsov and Chir-PIng Chang, Zh. fiz. Khim. 34, 2205 (1960).

28. V. I. Kravtsov and Pien-Tschao Yang, Vestnik. Lening. Univ. 17, 107 (1962).

29. G. P. Dezider'ev, S. I. Berenzina and G. A. Gorbachuk, Teor. i Prakt. Blestyashchikh. Gal'vanopkrytii. Akad. Nauk Lit. S.S.R. Inst. Khim. i Teknol. Osnovnye Materialy Vsees. Soveshch. Vilnyus, 123 (1962). C.A. 61, 292 (1965).

30. O. K. GAL'DIKene, V. I. DAGITE and YU. Yu. MATULIs, Issled. Obl. Galvanotekh. Novocherkassk 33 (1965). C.A. 66, 81830 (1967).

31. M. L. Kronengerg, J. C. Banter, E. Yeager and F. Hovorka, J. electrochem. Soc. 110, 100 (1963).

32. N. Sato and G. Okamoto, J. electrochem. Soc. 111, 897 (1964).

33. G. A. Di Bari and J. V. PeTrocelli. J. electrochem. Soc. 112, 99 (1965).

34. J. MindowicZ, Zes. Nauk Politech. Gdansk Chem. 58, 3 (1965), C.A. 64, 10757 (1966).

35. A. Faessler and R. Schmid, Z. Phys. 190, 10 (1966).

36. B. Baranowski and R. Wisniewsie, Bull. Acad. Polon. Sci., Ser. Sci. chim. 14, 273 (1966).

37. YU. A. BALOVNeV and I. I. TRETYAKov, Zh. fiz. Khim. 40, 1541 (1966).

38. S. L. KRICHMAR and K. E. AFENDIK, Elektrokhimiya 2, 600 (1966).

39. T. Shirasaky, A. Kitahara, S. Sakamoto and K. Morikawa. Denki Kagaku 34, 673 (1966), C.A. 66, 51590 (1967).

40. T. TAKeuchi and D. MiYatanI, Bull. chem. Soc. Japan, 40, 58 (1967).

41. Y. EnIsuzaki, W. J. Kass and M. O'KeEFe, J. chem. Phys. 46, 1378 (1967).

42. K. E. Heusler and L. Gaiser, Electrochim. Acta 13, 59 (1968).

43. YA. M. Kolotyrkin, Z. Elektrochem. 62, 664 (1958).

44. G. Okamoto, H. Kobayashi, M. Nagayama and N. Sato. Z. Elektrochem. 62, 775 (1958).

45. K. J. VeTTER and K. ARNOLD, Z. Elektrochem. 64, 244 (1960).

46. K. ARNOLD and K. J. VeTTER. Z. Elektrochem. 64, 407 (1960).

47. J. Osterwaid and H. H. Uhlig, J. electrochem. Soc. 108, 515 (1961).

48. J. TousEK, Colln. Czech. chem. Commun. 31, 3083 (1966).

49. G. F. SANDiekov and L. A. Uvarov, Zashch. Metal. 1, 636 (1965). C.A. 64, 10746 (1966).

50. T. S. DE Gromoboy and L. L. ShreIR, Electrochim. Acta 11, 895 (1966).

51. R. R. Sayano and K. Nobe. Calif. Univ. Water Resour. Center Contrib. No.109 (1965). C.A. 67, 87128 (1967).

52. K. SChWABE and G. Dietz. Z. Elektrochem. 62, 751 (1958).

53. E. KunZe and K. SchwaBe, Corros. Sci. 4, 109 (1964).

54. J. Mueller, Kinetika i Kataliz. 7, 188 (1966).

55. M. W. Roberts and B. R. Wells, Trans. Faraday Soc. 62, 1608 (1966).

56. R. L. PARK and H. E. FARnsworth, Surface Sci. 3, 287 (1965).

57. M. W. Roberts and B. R. Wells, Discuss. Faraday Soc. 41, 162 (1966).

58. T. A. Delchar, F. C. Tompkins and F. S. Ham., Proc. R. Soc. A300, 141 (1967).

59. YU. A. KLYACHKo and G. K. Boranowa, Zh. Uses, Khim. Obshch. Mendeleeva 10, 710 (1965). C.A. 64, 9231e (1966).

60. B. YA. Konjaev and V. A. KHITRov, Zashch. Metal. 2, 745 (1966). C.A. 66, 61234 (1967).

61. J. Postlethwaite and D. R. HuRP, Corrosion, 23, 109 (1967).

62. J. PostlethwaIte and D. R. HURP, Corros. Sci. 7, 435 (1967).

63. YA. M. Kolotyrkin, Zashch. Metal. 3, 131 (1967). C.A. 67, 60196 (1967).

64. J. O'M. Brockris, D. Drazic and A. R. Despic, Electrochim. Acta 4, 325 (1961).

65. W. J. LoRENZ and C. EICHKoRN, Ber. Bunsenges. physik. Chem. 70, 99 (1966).

66. K. E. Heusler, Z. Elektrochem. 62, 582 (1958); Ber. Bunsenges. Phys. Chem. 71, 620 (1967).

67. K. E. HeUSLER, Z. Elektrochem. 66, 177 (1962).

68. K. E. Heusler, Corros. Sci. 5, 183 (1965).

69. E. C. Snow, J. T. Weber and A. C. Switendick, J. appl. Phys. 37, 1342 (1966).

70. E. J. KELLY, J. electrochem. Soc. 112, 124 (1965).

71. J. J. Podrstá and A. J. Arvía, Electrochim. Acta 10, 159 (1965).

72. J. J. Podestá and A. J. ARvía, Electrochim. Acta. 10, 171 (1965).

73. A. J. ARvía and J. J. PodestÁ, Corros. Sci. 8, 203 (1968).

74. J. O'M. Bockris and E. C. PotTER, J. chem. Phys. 20, 614 (1952).

75. T. P. HoAR and J. G. HINES, J. Iron Steel Inst. 182, 124 (1956).

76. D. MacGillavry, J. Singer and J. H. Rosenbaum, J. Am. chem. Soc. 73, 1388 (1951).

77. D. MaCGillavry, J. Singer and J. H. Rosenbaum, J. chem. Phys. 19, 1195 (1951).

78. D. MacGillavey, J. H. Rosenbaum and R. W. Swenson, J. electrochem. Soc. 99, 22 (1956).

79. A. Lopez Lopez, C.r. hebd-Séanc. Acad. Sci., Paris 256, 2594 (1963). 
80. L. Colombier, C.r. hebd-Séanc Acad. Sci., Paris 199, 408 (1934).

81. J. Drozdov, Z. prikl. Khim. 22, 716 (1949).

82. J. M. WEST, Electrodeposition and Corrosion Processes. Van Nostrand, London (1965).

83. T. Markovic and M. AHMmdBane, Werkstoffe Korrosion 16, 212 (1965); T. Markovic, Werkstoffe Korrosion, 16, 570 (1965).

84. R. Suhrmann and G. Wedler. Z. physik. Chem. 10, 184 (1957)

85. R. Sumbuann, J. M. Heras, L. Viscido de Heras and G. Wedler, Ber. Bunsenges, physik. Chem. 68, 511 (1964).

86. R. Suhrmann, J. M. Heras, L. Viscido de Heras and G. Wedler, Ber. Bunsenges. physik. Chem. 68, 990 (1964).

87. YA. M. Kolotyrkin, Z. Elektrochem. 62, 50 (1958); J. electrochem. Soc. 108, 209 (1961). 